\title{
PENGARUH PEMBERIAN PUPUK ORGANIK CAIR BERBAHAN DASAR AIR LINDI DARI TPA TELAGA PUNGGUR TERHADAP PERTUMBUHAN MORFOMETRIK TANAMAN SELEDRI (Apium graveolens $\mathbf{L}$ )
}

\author{
Lani Puspita, Yarsi Effendi dan Mar Ayunis \\ Dosen Tetap Prodi Pendidikan Biologi Universitas Riau Kepulauan Batam
}

\begin{abstract}
ABSTRAK
Tempat Pengolahan Akhir (TPA) Sampah Telaga Punggur Kota Batam setiap harinya menerima 700-800 ton sampah dan dihasilkan 25-30 ton air lindi. Air limdi tersebut potensial untuk dijadikan pupuk organik cair. Untuk melihat pengaruh pupuk organik cair berbahan dasar air lindi dari TPA Telaga Punggur ini, dilakukan percobaan terhadap tanaman Seledri (Apium graveolens L). Penelitian ini bertujuan untuk: (1) mengetahui karaketeristik pupuk organik cair berbahan dasar air lindi, (2) membuktikan adanya pengaruh pemberian pupuk organik cair berbahan dasar air lindi terhadap pertumbuhan morfometrik tanaman Seledri (tinggi dan jumlah daun), (3) Mengetahui dosis optimum pupuk untuk pemupukan tanaman Seledri, dan (4) Mengetahui perbandingan tingkat pertumbuhan tanaman Seledri yang diberikan pupuk organik berbahan dasar air lindi dengan pupuk organik cair lain (dalam hal ini Pupuk NASA). Dari hasil penelitian didapatkan bahwa: (1) Kandungan Total NPK pada pupuk organik cair berbahan dasar lindi dari TPA Telaga Punggur adalah $511.37 \mathrm{mg} / \mathrm{l}$; (2) Pemberian pupuk organik cair berbahan dasar lindi dari TPA Telaga Punggur berpengaruh signifikan dan erat terhadap pertumbuhan tanaman Seledri (dalam ini pertumbuhan tinggi tanaman dan pertambahan jumlah daun); (3) Berdasarkan dosis yang diujicobakan, dosis pupuk organik cair lindi $14 \mathrm{ml} / \mathrm{L}$ memberikan hasil pertumbuhan terbaik, walau demikian, dosis ini belum merupakan dosis optimal dan dapat dilakukan uji coba lebih lanjut dengan dosis yang lebih besar dari $14 \mathrm{ml} / \mathrm{L}$; (4) Apabila dilihat dari variabel pertumbuhan tinggi tanaman, secara statistik pupuk organik cair lindi dan pupuk organik cair NASA memberikan hasil pertumbuhan yang sama; dan (5) Apabila dari dari variabel pertambahan jumlah daun, secara statistik pupuk organik cair lindi memberikan hasil pertumbuhan yang lebih baik dibandingkan pupuk organik cair NASA.
\end{abstract}

Kata kunci: pupuk organik, air lindi, Seledri (Apium graveolens L)

\section{PENDAHULUAN}

TPA Sampah Telaga Punggur di Kota Batam telah beroperasi sejak 1997 dengan luas sekitar 47 Ha. TPA Sampah ini sebetulnya direncanakan sebagai TPA dengan sistem control landfill, namun kenyataan di lapangan yang berjalan adalah sistem open dumping. Setiap harinya 700 - 800 ton sampah diterima TPA Punggur dan pada TPA ini dihasilkan $25-30$ ton air lindi/hari. Air lindi yang dihasilkan dari TPA sampah antara lain bisa dimanfaatkan untuk pembuatan pupuk organik cair, hal ini seperti yang diterapkan di TPA Rawa Kucing Kabupaten Tangerang (Puspita, 2007). Penelitian ini dimaksudkan untuk memanfaatkan potensi air lindi dari TPA Telaga Punggur untuk pembuatan pupuk organik cair, dalam penelitian ini tanaman 
yang digunakan untuk uji coba adalah Seledri. Tanaman Seledri merupakan salah satu jenis sayuran daun yang sudah lama dikenal oleh masyarakat. Seledri mempunyai aroma yang khas untuk menyedapkan masakan, selain itu Seledri juga dapat dimanfaatkan sebagai tanaman obat dan tanaman hias (Muhlisah, 1997).

Penelitian ini bertujuan untuk: (1) Membuktikan adanya pengaruh pemberian pupuk organik cair berbahan dasar air lindi terhadap pertumbuhan morfometrik tanaman Seledri, (2) Mengetahui dosis optimum pupuk organik cair berbahan dasar air lindi untuk pemupukan tanaman Seledri, dan (3) Mengetahui perbandingan tingkat pertumbuhan tanaman Seledri yang diberikan pupuk organik cair berbahan dasar air lindi dengan pupuk organik cair lain (dalam hal ini yang digunakan sebagai pembanding adalah Pupuk NASA). Penelitian ini diharapkan dapat memberikan informasi mengenai alternatif pemanfaatan air lindi yang banyak dihasilkan di TPA Telaga Punggur.

\section{METODE PENELITIAN}

\section{Waktu dan Lokasi Penelitian}

Penelitian dilakukan pada bulan April - Juni 2013. Penelitian diawali dengan pengambilan sampel air lindi dari Instalasi Pengolahan Air Limbah (IPAL) di TPA Telaga Punggur, lalu dilanjutkan dengan pengolahan air lindi menjadi pupuk organik cair dengan penambahan bakteri starter. Untuk mengetahui karakteristik pupuk organik cair berbahan dasar air lindi tersebut, dilakukan analisis kualitas pupuk organik cair tersebut dengan menggunakan jasa pihak ketiga (yaitu Laboratorium Produktivitas Lingkungan (ProLing) Perairan Institut Pertanian Bogor (IPB)). Pembuatan pupuk organik cair berbahan dasar air lindi dan pemberian perlakuan terhadap tanaman Seledri dilakukan di Perumahan Cendana Blok A7 No. 24 Kota Batam.

\section{Alat dan Bahan}

Peralatan yang digunakan pada penelitian ini adalah: jerigen volume 10 liter 2 buah, gayung bertangkai 1 buah, ember hitam berkapasitas 70 liter, batang pengaduk dari kayu, pot berdiameter $15 \mathrm{~cm}$ dan tinggi $20 \mathrm{~cm}$ sebanyak 20 buah, kotak semai ukuran $50 \mathrm{~cm}$ x $20 \mathrm{~cm}$ x $10 \mathrm{~cm}$ sebanyak 1 buah, gelas piala ukuran $250 \mathrm{ml}$, paranet, gunting, dan alat penyiram tanaman. Bahan-bahan yang digunakan pada penelitian ini adalah: air lindi dari TPA Telaga Punggur sebanyak 20 liter, cairan bakteri starter sebanyak 1 liter (berisi Azetobacter, Lactobacillus, dan Streptomyces), glukosa/gula pasir, benih Seledri, air keran, dan tanah yang diambil dari lahan pertanian yang baru dipanen.

\section{Prosedur Pelaksanaan Penelitian}

Penelitian ini dilaksanakan dengan tahapan kegiatan sebagai berikut:

1. Pengambilan air lindi dari IPAL TPA Telaga Punggur sebanyak 20 liter.

2. Pengolahan air lindi menjadi pupuk organik cair. Hal ini dilakukan dengan cara sbb:

a) Air lindi yang sudah diendapkan selama 7 hari dimasukkan ke dalam ember berkapasitas 20 liter. Selanjutnya ke dalam ember tersebut ditambahkan bakteri starter sebanyak 1 liter.

b) Aduk air lindi dan bakteri starter dengan batang pengaduk. Selama proses fermentasi, renggangkan tutup ember agar gas hasil fermentasi dapat bebas keluar. 
c) Simpan ember campuran tersebut di tempat yang tidak terkena cahaya matahari selama 7 - 14 hari sampai proses fermentasi selesai.

d) Saring larutan terlebih dahulu sebelum digunakan sebagai pupuk cair.

e) Ambil $500 \mathrm{ml}$ larutan pupun organik cair berbahan air lindi tersebut untuk dianalisis kandungan total Nitrogen-Phosphor-Kaliam (NPK), unsur mikro, dan unsur makronya di laboratorium.

3. Pemilihan pupuk pembanding. Pupuk pembanding yang digunakan adalah Pupuk Organik Cair NASA. Pupuk NASA merupakan pupuk organik cair dari ekstraksi bahan organik limbah ternak unggas, limbah tanaman, limbah alam, dan zat alami lainnya. Pupuk pembanding ini dipilih antara lain karena: (1) dapat digunakan untuk semua jenis tanaman pangan, holtikultura, dan tanaman tahunan, (2) dapat digunakan dengan mudah secara disemprot atau disiram, dan (3) mudah membelinya karena banyak beredar di pasaran.

4. Persiapan media tanam, dalam hal ini menggunakan tanah yang diambil dari lahan pertanian yang baru dipanen, tanah tersebut dihomogenkan dengan cara diayak, selanjutnya tanah ditimbang sebanyak 500 gram untuk disimpan di masing-masing pot.

5. Persiapan pembibitan. Pembibitan dilakukan di kotak semai hingga berkecambah

6. Uji perlakuan pada tanaman Seledri. Uji perlakuan terdiri dari 2 tahapan, yaitu:

a) Penentuan dosis untuk uji coba. Berdasarkan hasil analisis laboratorium, didapatkan data bahwa kandungan NPK total pada air lindi adalah $511.37 \mathrm{mg} / \mathrm{l}$. Merujuk pada label kemasan Pupuk NASA, kandungan total NPK pada pupuk Nasa adalah $1800 \mathrm{mg} / \mathrm{l}$. Dengan demikian, perbandingan kandungan total NPK antara pupuk organik cair berbahan air lindi dan Pupuk NASA adalah $1: 3.5$, atau kandungan NPK dalam $1 \mathrm{ml}$ Pupuk NASA setara dengan kandungan NPK dalam $3.5 \mathrm{ml}$ pupuk organik cair berbahan dasar air lindi.

b) Pengujian untuk mengetahui dosis optimum pupuk organik cair berbahan air lindi (atau cukup disebut "pupuk organik cair lindi"). Dosis pupuk organik cair berbahan air lindi yang digunakan adalah kelipatan $3.5 \mathrm{ml}$, sehingga dosis yang diujicobakan adalah: 3.5 ml, $7 \mathrm{ml}, 10.5 \mathrm{ml}$, dan $14 \mathrm{ml}$. Dosis Pupuk Organik Cair NASA (atau cukup disebut "pupuk NASA") yang digunakan adalah $1 \mathrm{ml}, 2 \mathrm{ml}, 3 \mathrm{ml}$, dan $4 \mathrm{ml}$.

\section{Metode Analisis Data}

Analisis data yang digunakan adalah Analisis Regresi dan Uji-t. Analisis regresi digunakan untuk melihat pengaruh pemakaian pupuk organik berbahan air lindi dengan dosis yang berbeda. Variabel pertumbuhan tanaman Seledri yang digunakan adalah tinggi tanaman dan jumlah daun. Uji-t digunakan untuk mengetahui ada/tidaknya perbedaan pertumbuhan morfometri Seledri antara penggunaan pupuk organik cair lindi dengan pupuk NASA. Analisis data dilakukan dengan bantuan aplikasi Minitab Versi 14.

\section{HASIL DAN PEMBAHASAN}

\section{Karakteristik Pupuk Organik Cair Berbahan Dasar Air Lindi}

Sebelum diujicobakan ke tanaman, pupuk organik cair lindi yang telah dibuat diperiksa dulu karakteristiknya di Laboratorium ProLing Perairan IPB. Pada Tabel 1 di bawah ini 
disajikan hasil analisis kualitas pupuk organik cair tersebut. Berdasarkan hasil analisis laboratorium, didapatkan data bahwa kandungan NPK total pada pupuk organik cair lindi adalah $511.37 \mathrm{mg} / \mathrm{l}$. Merujuk pada label kemasan Pupuk NASA, kandungan total NPK pada pupuk NASA adalah $1800 \mathrm{mg} / \mathrm{l}$. Dengan demikian, perbandingan kandungan total NPK antara pupuk organik cair lindi dan Pupuk NASA adalah 1 : 3.5, atau kandungan NPK dalam $1 \mathrm{ml}$ Pupuk NASA setara dengan $3.5 \mathrm{ml}$ pupuk organik cair lindi.

Tabel 1. Hasil Analisis Kualitas Pupuk Organik Cair Lindi

\begin{tabular}{|c|c|c|c|c|c|}
\hline NO. & PARAMETER & SATUAN & $\begin{array}{c}\text { LIMIT } \\
\text { DETEKSI }\end{array}$ & NILAI & $\begin{array}{c}\text { ALAT/ } \\
\text { METODE *) }\end{array}$ \\
\hline 1 & Total N & $\mathrm{mg} / \mathrm{l}$ & 0.010 & 43.97 & APHA, ed. $22,2012,4500-\mathrm{N}$ \\
\hline 2 & Total Fosfat & $\mathrm{mg} / \mathrm{l}$ & 0.005 & 13.31 & APHA, ed. 22, 2012, 4500-P-E \\
\hline 3 & Kalium (K) & $\mathrm{mg} / \mathrm{l}$ & 0.005 & 454.09 & APHA, ed. 22, 2012, 3110 \\
\hline 4 & Magnesium (Mg) & $\mathrm{mg} / \mathrm{l}$ & 0.005 & 83.36 & APHA, ed. 22, 2012, 3110 \\
\hline 5 & Kalsium $(\mathrm{Ca})$ & $\mathrm{mg} / \mathrm{l}$ & 0.005 & 38.02 & APHA, ed. $22,2012,3110$ \\
\hline 6 & Natrium (Na) & $\mathrm{mg} / \mathrm{l}$ & 0.005 & 175.31 & APHA, ed. 22, 2012, 3110 \\
\hline 7 & Aluminium (Al) & $\mathrm{mg} / \mathrm{l}$ & 0.005 & $<0.005$ & APHA, ed. 22, 2012, 3110 \\
\hline 8 & Seng $(\mathrm{Zn})$ & $\mathrm{mg} / \mathrm{l}$ & 0.005 & $0>073$ & APHA, ed. $22,2012,3110$ \\
\hline 9 & Tembaga $(\mathrm{Cu})$ & $\mathrm{mg} / \mathrm{l}$ & 0.005 & 0.054 & APHA, ed. 22, 2012, 3110 \\
\hline 10 & Boron (B) & $\mathrm{mg} / \mathrm{l}$ & 0.005 & $<0.005$ & APHA, ed. 22, 2012, 3110 \\
\hline 11 & Mangan (Mn) & $\mathrm{mg} / \mathrm{l}$ & 0.005 & 0.557 & APHA, ed. 22, 2012, 3110 \\
\hline
\end{tabular}

Uji Pendahuluan untuk Penentuan Dosis Pemberian Pupuk Organik Cair Lindi pada Tanaman Percobaan

Untuk menentukan berapa dosis pupuk organik cair yang perlu diberikan ke tanaman percobaan agar menghasilkan pertumbuhan yang baik, dilakukan uji pendahuluan. Pada uji pendahuluan ini digunakan 4 macam dosis pupuk organik cair lindi, yaitu: $3.5 \mathrm{ml} / \mathrm{L}, 7 \mathrm{ml} / \mathrm{L}$, $10.5 \mathrm{ml} / \mathrm{L}$, dan $14 \mathrm{ml} / \mathrm{L}$. Satuan $\mathrm{ml} / \mathrm{L}$ yang dimaksud dalam hal ini adalah jumlah $\mathrm{ml}$ pupuk organik cair lindi yang dilarutkan dalam 1 liter air pengencer (air keran). Uji pendahuluan dilakukan terhadap variabel pertambahan tinggi tanaman Seledri dan pertambahan jumlah daun tanaman Seledri. Uji pendahuluan dilakukan 5 kali ulangan. Uji diawali dengan memindahkan bibit tanaman Seledri dari kotak semai ke pot tanaman pada umur 4 minggu (pada saat pemindahan dipilih tanaman Seledri yang tingginya homogen $2 \mathrm{~cm}$ dan jumlah daunnya 2 helai), setelah dipindahkan diberikan perlakuan dengan 4 macam dosis pupuk tersebut. Pengukuran pertambahan tinggi tanaman Seledri dan perhitungan pertambahan jumlah daun tanaman Seledri dilakukan pada minggu ketiga setelah pemberian perlakuan.

Data pertambahan tinggi tanaman Seledri pada uji pendahuluan disajikan pada Tabel 2. Pada tabel tersebut dapat dilihat bahwa rata-rata pertambahan tinggi tanaman Seledri terbesar terdapat pada tanaman Seledri yang diberikan dosis pupuk organik cair lindi $14 \mathrm{ml} / \mathrm{L}$; rata-rata tingginya adalah $2.36 \mathrm{~cm}$. Sedangkan rata-rata pertambahan tinggi tanaman Seledri terendah adalah $1.78 \mathrm{~cm}$, yang terdapat pada pemberian dosis pupuk organik cair lindi $3.5 \mathrm{ml} / \mathrm{L}$. Data dosis pupuk organik cair lindi (sebagai variabel $\mathrm{X}$ ) dan data pertambahan tinggi tanaman Seledri (sebagai variabel Y) kemudian diregresikan, dan hasil analisis regresi disajikan pada 
Gambar 1. Dari hasil analisis regresi tersebut didapatkan bahwa koefiesi determinasi $\left(\mathrm{R}^{2}\right)$ antara variabel dosis pupuk organik cair lindi dan pertambahan tinggi tanaman Seledri adalah $86.9 \%$, sehingga koefisien regresinya (R) adalah $93.22 \%$. P-value dari analisis regresi tersebut adalah 0.068 (nilainya $<0.1$ atau persamaan regresi dapat diterima pada selang kepercayaan 90\%). Dengan demikian dapat disebutkan bahwa terdapat hubungan yang signifikan dan erat antara pemberian dosis pupuk organik cair lindi dengan pertambahan tinggi tanaman Seledri. Pada Gambar 1 dapat dilihat bahwa semakin tinggi dosis maka semakin besar pertambahan tinggi tanaman Seledri; pada grafik tersebut dapat kita lihat bahwa dosis $14 \mathrm{ml} / \mathrm{L}$ mungkin belum merupakan dosis optimum namun dosis tersebut adalah dosis terbaik dari keempat macam dosis yang dicobakan pada penelitian ini.

Tabel 2. Data Pertambahan Tinggi Tanaman Seledri dengan Empat Macam Dosis Pemberian Pupuk organik cair lindi

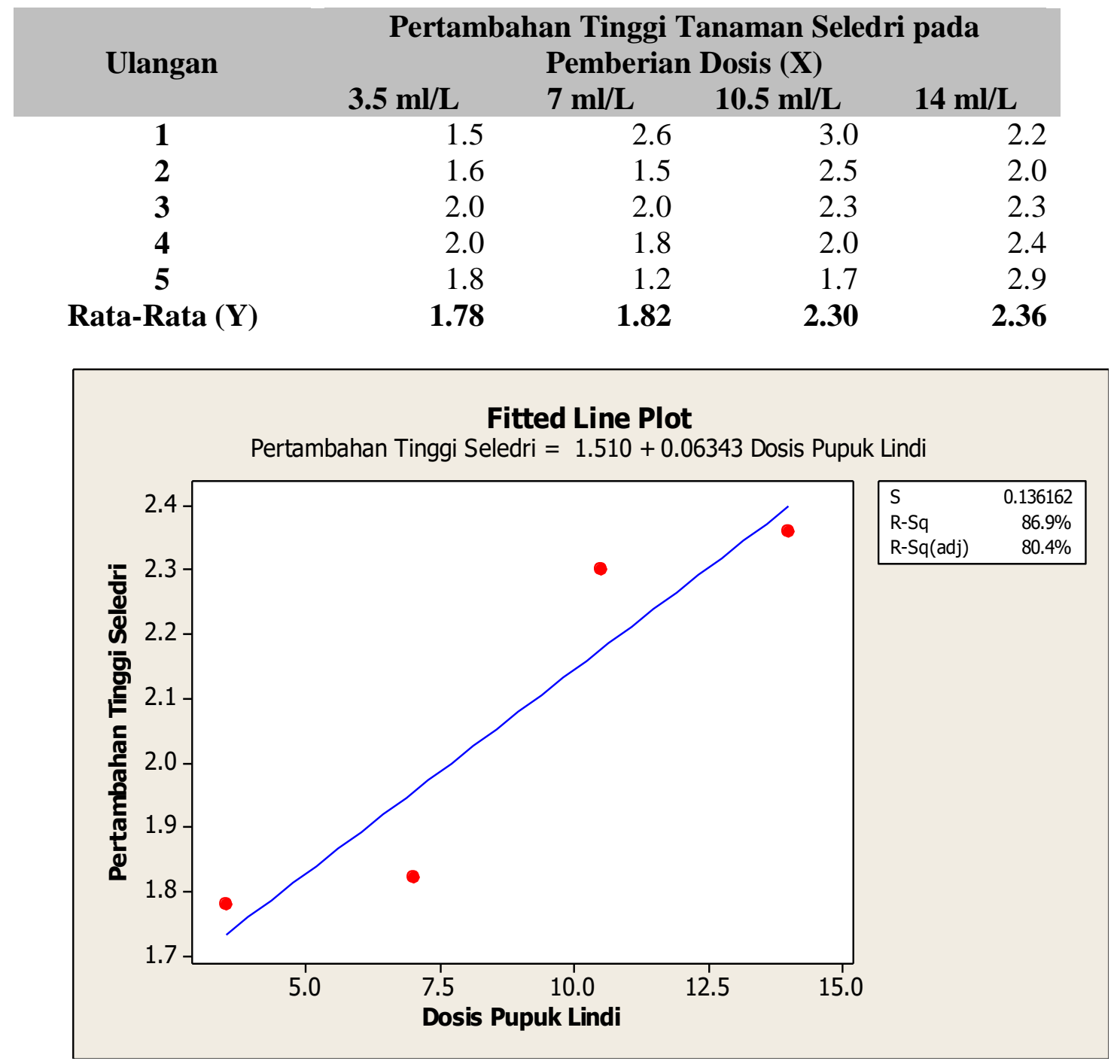




\section{Gambar 1. Grafik Regresi Linear Sederhana antara Variable Dosis Pupuk Organik Cair Lindi (X) dengan Pertambahan Tinggi Tanaman Seledri}

Data pertambahan jumlah daun tanaman Seledri pada uji pendahuluan disajikan pada Tabel 3. Pada tabel tersebut dapat dilihat bahwa rata-rata pertambahan jumlah daun tanaman Seledri terbesar terdapat pada tanaman Seledri yang diberikan dosis pupuk organik cair lindi $10.5 \mathrm{ml} / \mathrm{L}$ dan $14 \mathrm{ml} / \mathrm{L}$; rata-rata pertambahan jumlah daunnya adalah 3.6 helai. Sedangkan rata-rata pertambahan jumlah daun tanaman Seledri terendah adalah 3.2 helai, yang terdapat pada pemberian dosis pupuk organik cair lindi $3.5 \mathrm{ml} / \mathrm{L}$. Data dosis pupuk organik cair lindi (sebagai variabel X) dan data pertambahan jumlah daun tanaman Seledri (sebagai variabel Y) kemudian diregresikan, dan hasil analisis regresi disajikan pada Gambar 2. Dari hasil analisis regresi tersebut didapatkan bahwa koefiesi determinasi $\left(\mathrm{R}^{2}\right)$ antara variabel dosis pupuk organik cair lindi dan pertambahan jumlah daun tanaman Seledri adalah 89.1\%, sehingga koefisien regresinya $(\mathrm{R})$ adalah $94.39 \%$. P-value dari analisis regresi tersebut adalah 0.056 (nilainya $<0.1$ atau persamaan regresi dapat diterima pada selang kepercayaan $90 \%$ ). Dengan demikian dapat disebutkan bahwa terdapat hubungan yang signifikan dan erat antara pemberian dosis pupuk organik cair lindi dengan pertambahan tinggi tanaman Seledri. Pada Gambar 2 dapat dilihat bahwa semakin tinggi dosis maka semakin besar pertambahan jumlah daun tanaman Seledri; pada grafik tersebut dapat kita lihat bahwa dosis $14 \mathrm{ml} / \mathrm{L}$ mungkin belum merupakan dosis optimum namun dosis tersebut adalah dosis terbaik dari keempat macam dosis yang dicobakan pada penelitian ini.

Tabel 3. Data Pertambahan Jumlah Daun Tanaman Seledri dengan Empat Macam Dosis Pemberian Pupuk Organik Cair Lindi

\begin{tabular}{|c|c|c|c|c|}
\hline \multirow[t]{2}{*}{ Ulangan } & \multicolumn{4}{|c|}{$\begin{array}{c}\text { Pertambahan Jumlah Daun Tanaman Seledri pada } \\
\text { Pemberian Dosis (X) }\end{array}$} \\
\hline & $3.5 \mathrm{ml} / \mathrm{L}$ & $7 \mathrm{ml} / \mathrm{L}$ & $10.5 \mathrm{ml} / \mathrm{L}$ & 14 ml/L \\
\hline 1 & 3 & 3 & 4 & 4 \\
\hline 2 & 3 & 4 & 3 & 3 \\
\hline 3 & 3 & 3 & 4 & 3 \\
\hline 4 & 4 & 4 & 4 & 4 \\
\hline 5 & 3 & 3 & 3 & 4 \\
\hline Rata-Rata (Y) & 3.2 & 3.4 & 3.6 & 3.6 \\
\hline
\end{tabular}




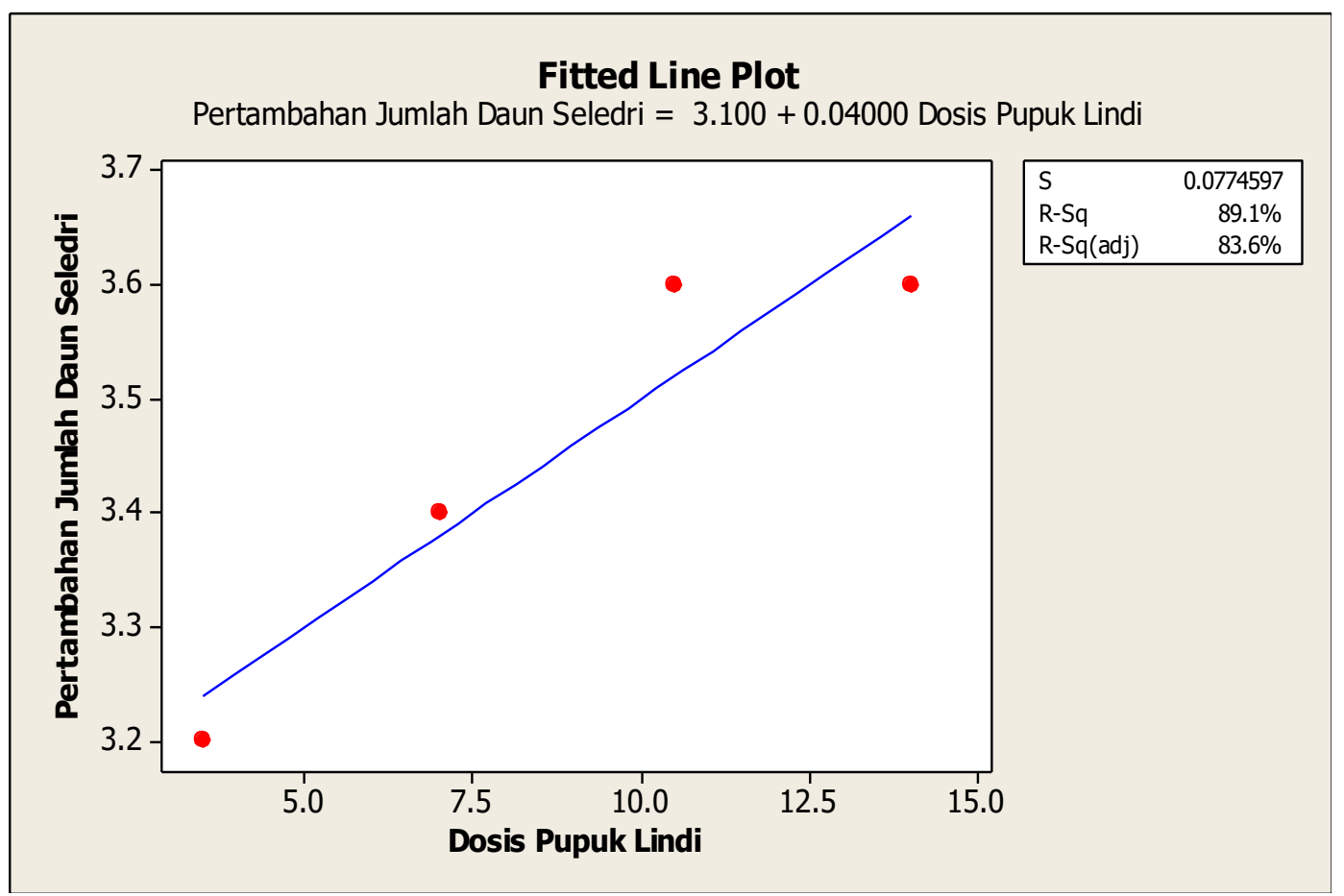

\section{Gambar 2. Grafik Regresi Linear Sederhana antara Variable Dosis Pupuk Organik Cair Lindi (X) dengan Pertambahan Jumlah Daun Tanaman Seledri}

Uji Utama untuk Membandingkan Efektivitas Pertumbuhan Tanaman Seledri Antara Tanaman yang Diberi Pupuk organik cair lindi dan Tanaman yang Diberi Pupuk NASA

Dari uji pendahuluan diketahui bahwa dosis pupuk organik cair lindi yang memberikan hasil pertumbuhan terbaik adalah dosis $14 \mathrm{ml} / \mathrm{L}$. Dari hasil uji laboratorium juga diketahui bahwa perbandingan kandungan NPK antara pupuk organik cair lindi dari pupuk NASA adalah $1: 3.5$, atau kandungan NPK pada $3.5 \mathrm{ml} / \mathrm{L}$ pupuk organik cair lindi sama dengan kandungan NPK $1 \mathrm{ml} / \mathrm{L}$ pupuk NASA. Dengan demikian, pada uji utama ini digunakan dosis $14 \mathrm{ml} / \mathrm{L}$ pupuk organik cair lindi yang dibandingkan dengan dosis $4 \mathrm{ml} / \mathrm{L}$ pupuk NASA, dengan dasar bahwa kedua dosis tersebut sama-sama mengandung total NPK yang sama.

Uji utama dilakukan terhadap variabel tinggi tanaman Seledri dan jumlah daun tanaman Seledri. Uji utama dilakukan sebanyak 10 kali ulangan. Uji diawali dengan memindahkan bibit tanaman Seledri dari kotak semai ke pot tanaman pada umur 4 minggu (pada saat pemindahan dipilih tanaman Seledri yang tingginya homogen $2 \mathrm{~cm}$ dan jumlah daunnya 2 helai). Setelah dipindahkan, tanaman tersebut diberikan perlakuan yang berbeda (dosis pupuk organik cair lindi $14 \mathrm{ml} / \mathrm{L}$ dan pupuk NASA $4 \mathrm{ml} / \mathrm{L}$, masing-masing 10 kali ulangan). Pengukuran tinggi tanaman dan perhitungan jumlah daun dilakukan setiap minggu, mulai dari minggu pertama setelah perlakuan, hingga minggu ketiga setelah perlakuan.

Pada Tabel 4 di bawah ini disajikan data tinggi tanaman mulai dari pertama kali dipindahkan dari kotak semai ke pot, hingga minggu ketiga setelah pemberian perlakuan. Dari data pada tabel tersebut dapat dilihat bahwa tanaman Seledri yang diberikan pupuk organik cair lindi memiliki rata-rata tinggi tanaman yang lebih besar daripada tanaman Seledri yang diberikan pupuk NASA. Tanaman Seledri yang diberikan pupuk organik cair lindi rata-rata memiliki tinggi $4.83 \mathrm{~cm}$, sedangkan tanaman Seledri yang diberikan pupuk NASA rata-rata memiliki tinggi $4.48 \mathrm{~cm}$. Tinggi maksimal tanaman Seledri yang diberikan pupuk organik cair 
lindi adalah $6.0 \mathrm{~cm}$ dan tinggi minimalnya adalah $3.3 \mathrm{~cm}$; sedangkan tinggi maksimal tanaman Seledri yang diberikan pupuk NASA adalah $5.0 \mathrm{~cm}$ dan tinggi minimalnya adalah $4.0 \mathrm{~cm}$. Dengan membandingkan data pertambahan tinggi tanaman Seledri pada minggu pertama dan kedua antara kedua macam pupuk, dapat dilihat bahwa pada minggu pertama dan kedua tersebut pupuk NASA memberikan hasil pertumbuhan yang lebih baik dibandingkan pupuk organik cair lindi, namun pada minggu ketiga pupuk organik cair lindi memberikan hasil pertumbuhan yang jauh lebih baik daripada pupuk NASA. Di akhir pengamatan (minggu ketiga), pupuk organik cair lindi memberikan hasil pertumbuhan tinggi tanaman Seledri yang jauh lebih baik daripada pupuk NASA; hal ini diprediksi karena bentuk senyawa NPK pada pupuk organik cair lindi lebih kompleks daripada pupuk NASA sehingga pada pupuk organik cair lindi diperlukan waktu lebih lama untuk penguraian dan dapat dimanfaatkan oleh tanaman Seledri. Dari hasil uji statistik menggunakan Uji T, didapatkan bahwa $\mathrm{T}_{\text {hitung }}$ adalah 0.92 dan $\mathrm{T}_{(0.05,18)}$ adalah 1.73; dengan demikian dapat dikatakan bahwa secara statistik kedua jenis pupuk organik tersebut (pupuk organik cair lindi dan pupuk NASA) memberikan efek pertumbuhan tinggi tanaman Seledri yang sama.

Menurut Syahrudin (2012), pertambahan tinggi tanaman sangat dipengaruhi oleh faktor genetik dan ketersedian unsur hara dalam jumlah yang cukup dan berimbang. Menurut Lingga dan Marsono (2001) dalam Syahrudin (2012), unsur nitrogen sangat penting untuk pertumbuhan vegetatif tanaman karena dapat merangkan pertumbuhan secara keseluruhan. Menurut Laegried (1999) dalam Hindarsah dan Simarmata (2004) dalam Syahrudin (2012), ketersediaan nitrogen adalah penting pada saat pertumbuhan tanaman, karena nitrogen berperan dalam proses biokimia tanaman. Pada data di Tabel 1 dapat kita lihat bahwa kandungan Total N pada pupuk organik cair lindi adalah $43.97 \mathrm{mg} / \mathrm{l}$.

Selain dari nitrogen, untuk meningkatkan laju pertambahan tinggi tanaman Seledri juga dibutuhkan unsur fosfor. Menurut Rosmarkan dan Yuwono (2002), fosfor berperan dalam pembentukan sejumlah protein, fotosintesis, dan sistem perakaran tanaman. Pada data di Tabel 1 dapat kita lihat bahwa kandungan Total P pada pupuk organik cair lindi adalah $13.31 \mathrm{mg} / \mathrm{l}$.

Tabel 4. Data Pertumbuhan Tinggi Tanaman Seledri dengan Perlakuan Pupuk Organik Cair Lindi dan Pupuk NASA

\begin{tabular}{|c|c|c|c|c|c|c|c|c|c|c|}
\hline \multirow{3}{*}{$\begin{array}{l}\text { Ulangan } \\
\text { ke- }\end{array}$} & \multicolumn{5}{|c|}{$\begin{array}{c}\text { Data untuk Perlakuan Pemberian } \\
\text { Pupuk Organik Cair Lindi } \\
\text { Pertambahan Tinggi }\end{array}$} & \multicolumn{5}{|c|}{$\begin{array}{c}\text { Data untuk Perlakuan Pemberian } \\
\text { Pupuk NASA } \\
\text { Pertambahan Tinggi }\end{array}$} \\
\hline & \multirow[t]{2}{*}{$\begin{array}{l}\text { Tinggi } \\
\text { Awal } \\
(\mathbf{c m})\end{array}$} & \multicolumn{3}{|c|}{$\begin{array}{l}\text { Tanaman pada } \\
\text { Minggu } \\
(\mathbf{c m} / \mathbf{m i n g g u})\end{array}$} & \multirow[t]{2}{*}{$\begin{array}{l}\text { Tinggi } \\
\text { Akhir } \\
(\mathbf{c m})\end{array}$} & \multirow[t]{2}{*}{$\begin{array}{l}\text { Tinggi } \\
\text { Awal } \\
(\mathrm{cm})\end{array}$} & \multicolumn{3}{|c|}{$\begin{array}{l}\text { Tanaman pada } \\
\text { Minggu } \\
(\mathbf{c m} / \text { minggu })\end{array}$} & \multirow[t]{2}{*}{$\begin{array}{l}\text { Tinggi } \\
\text { Akhir } \\
\text { (cm) }\end{array}$} \\
\hline & & I & II & III & & & I & II & III & \\
\hline 1 & 2 & 0.3 & 0.5 & 0.7 & 3.5 & 2 & 0.3 & 0.7 & 2.0 & 5.0 \\
\hline 2 & 2 & 0.2 & 0.6 & 3.2 & 6.0 & 2 & 0.8 & 0.5 & 1.2 & 4.5 \\
\hline 3 & 2 & 0.4 & 0.5 & 3.1 & 6.0 & 2 & 0.5 & 0.5 & 1.3 & 4.3 \\
\hline 4 & 2 & 0.2 & 0.8 & 3.0 & 6.0 & 2 & 0.8 & 0.8 & 0.4 & 4.0 \\
\hline 5 & 2 & 0.4 & 0.4 & 3.2 & 6.0 & 2 & 0.9 & 0.9 & 1.2 & 5.0 \\
\hline 6 & 2 & 0.2 & 0.4 & 2.4 & 5.0 & 2 & 0.3 & 0.8 & 1.4 & 4.5 \\
\hline 7 & 2 & 0.4 & 0.3 & 0.8 & 3.5 & 2 & 0.7 & 1.0 & 1.3 & 5.0 \\
\hline 8 & 2 & 0.5 & 0.2 & 1.8 & 4.5 & 2 & 0.5 & 1.3 & 0.7 & 4.5 \\
\hline 9 & 2 & 0.3 & 0.2 & 0.8 & 3.3 & 2 & 0.2 & 1.3 & 0.5 & 4.0 \\
\hline 10 & 2 & 0.2 & 0.3 & 2.0 & 4.5 & 2 & 0.8 & 0.7 & 0.5 & 4.0 \\
\hline Rata-Rata & 2 & 0.3 & 0.4 & 2.1 & 4.8 & 2 & 0.6 & 0.9 & 1.1 & 4.5 \\
\hline Maksimal & 2 & 0.5 & 0.8 & 3.2 & 6.0 & 2 & 0.9 & 1.3 & 2.0 & 5.0 \\
\hline Minimal & 2 & 0.2 & 0.2 & 0.7 & 3.3 & 2 & 0.2 & 0.5 & 0.4 & 4.0 \\
\hline
\end{tabular}


Pada Tabel 5 di bawah ini disajikan data jumlah daun tanaman Seledri mulai dari pertama kali dipindahkan dari kotak semai ke pot, hingga minggu ketiga setelah pemberian perlakuan. Dari data pada tabel tersebut dapat dilihat bahwa tanaman Seledri yang diberikan pupuk organik cair lindi memiliki rata-rata jumlah daun yang lebih banyak daripada tanaman Seledri yang diberikan pupuk NASA. Tanaman Seledri yang diberikan pupuk organik cair lindi rata-rata memiliki jumlah daun 5.5 helai, sedangkan tanaman Seledri yang diberikan pupuk NASA rata-rata memiliki jumlah daun 4.9 helai. Jumlah daun maksimal tanaman Seledri yang diberikan pupuk organik cair lindi adalah 6 helai, hal ini sama dengan jumlah daun maksimal yang diberikan perlakuan pupuk NASA. Jumlah daun minimal tanaman Seledri yang diberikan pupuk organik cair lindi adalah 5 helai, sedangkan jumlah daun minimal tanaman Seledri yang diberikan pupuk NASA adalah 4 helai. Dari hasil uji statistik menggunakan Uji T, didapatkan bahwa $\mathrm{T}_{\text {hitung }}$ adalah 2.09 dan $\mathrm{T}_{(0.05,18)}$ adalah 1.73; dengan demikian dapat dikatakan bahwa secara statistik kedua jenis pupuk organik tersebut (pupuk organik cair lindi dan pupuk NASA) memberikan efek pertumbuhan jumlah daun yang berbeda, yang mana pupuk organik cair lindi memberikan hasil pertumbuhan yang lebih baik daripada pupuk NASA. Pada tanaman Seledri, bagian tubuh yang dimanfaatkan adalah daunnya; dengan demikian untuk memperoleh hasil panen yang baik dapat dikatakan bahwa pupuk organik cair lindi memberikan hasil yang lebih baik. Grafik Boxplot yang membandingkan perbedaan nilai tengah dan nilai sebaran jumlah daun pada tanaman Seledri yang diberikan perlakuan pupuk organik cair lindi dengan pupuk NASA disajikan pada Gambar 3.

Tabel 5. Data Jumlah Daun Tanaman Seledri dengan Perlakuan Pupuk organik cair lindi dan Pupuk NASA

\begin{tabular}{|c|c|c|c|c|c|c|c|c|c|c|}
\hline \multirow{3}{*}{$\begin{array}{l}\text { Ulangan } \\
\text { ke- }\end{array}$} & \multicolumn{5}{|c|}{$\begin{array}{l}\text { Data untuk Perlakuan Pemberian } \\
\text { Pupuk Organik Cair Lindi }\end{array}$} & \multicolumn{5}{|c|}{$\begin{array}{c}\text { Data untuk Perlakuan Pemberian } \\
\text { Pupuk NASA }\end{array}$} \\
\hline & \multirow[t]{2}{*}{$\begin{array}{c}\text { Jumlah } \\
\text { Daun } \\
\text { Awal } \\
\text { (helai) }\end{array}$} & \multicolumn{3}{|c|}{$\begin{array}{l}\text { Pertambahan } \\
\text { Jumlah Daun } \\
\text { pada Minggu } \\
\text { (helai/minggu) }\end{array}$} & \multirow[t]{2}{*}{$\begin{array}{c}\text { Jumlah } \\
\text { Daun } \\
\text { Akhir } \\
\text { (helai) }\end{array}$} & \multirow[t]{2}{*}{$\begin{array}{c}\text { Jumlah } \\
\text { Daun } \\
\text { Awal } \\
\text { (helai) }\end{array}$} & \multicolumn{3}{|c|}{$\begin{array}{c}\text { Pertambahan } \\
\text { Jumlah Daun pada } \\
\text { Minggu } \\
\text { (helai/minggu) }\end{array}$} & \multirow[t]{2}{*}{$\begin{array}{l}\text { Jumlah } \\
\text { Daun } \\
\text { Akhir } \\
\text { (helai) }\end{array}$} \\
\hline & & I & II & III & & & I & II & III & \\
\hline 1 & 2 & 2 & 2 & 0 & 6 & 2 & 1 & 2 & 0 & 5 \\
\hline 2 & 2 & 1 & 1 & 1 & 5 & 2 & 1 & 1 & 1 & 5 \\
\hline 3 & 2 & 1 & 2 & 1 & 6 & 2 & 1 & 2 & 1 & 6 \\
\hline 4 & 2 & 2 & 1 & 1 & 6 & 2 & 2 & 1 & 1 & 6 \\
\hline 5 & 2 & 2 & 1 & 0 & 5 & 2 & 1 & 1 & 1 & 5 \\
\hline 6 & 2 & 1 & 1 & 1 & 5 & 2 & 1 & 1 & 0 & 4 \\
\hline 7 & 2 & 2 & 0 & 1 & 5 & 2 & 2 & 0 & 1 & 5 \\
\hline 8 & 2 & 1 & 1 & 1 & 5 & 2 & 1 & 1 & 0 & 4 \\
\hline 9 & 2 & 1 & 2 & 1 & 6 & 2 & 1 & 1 & 0 & 4 \\
\hline 10 & 2 & 1 & 2 & 1 & 6 & 2 & 1 & 2 & 0 & 5 \\
\hline Rata-Rata & 2 & 1.4 & 1.3 & 0.8 & 5.5 & 2 & 1.2 & 1.2 & 0.5 & 4.9 \\
\hline Maksimal & 2 & 2 & 2 & 1 & 6 & 2 & 2 & 2 & 1 & 6 \\
\hline Minimal & 2 & 1 & 0 & 0 & 5 & 2 & 1 & 0 & 0 & 4 \\
\hline
\end{tabular}




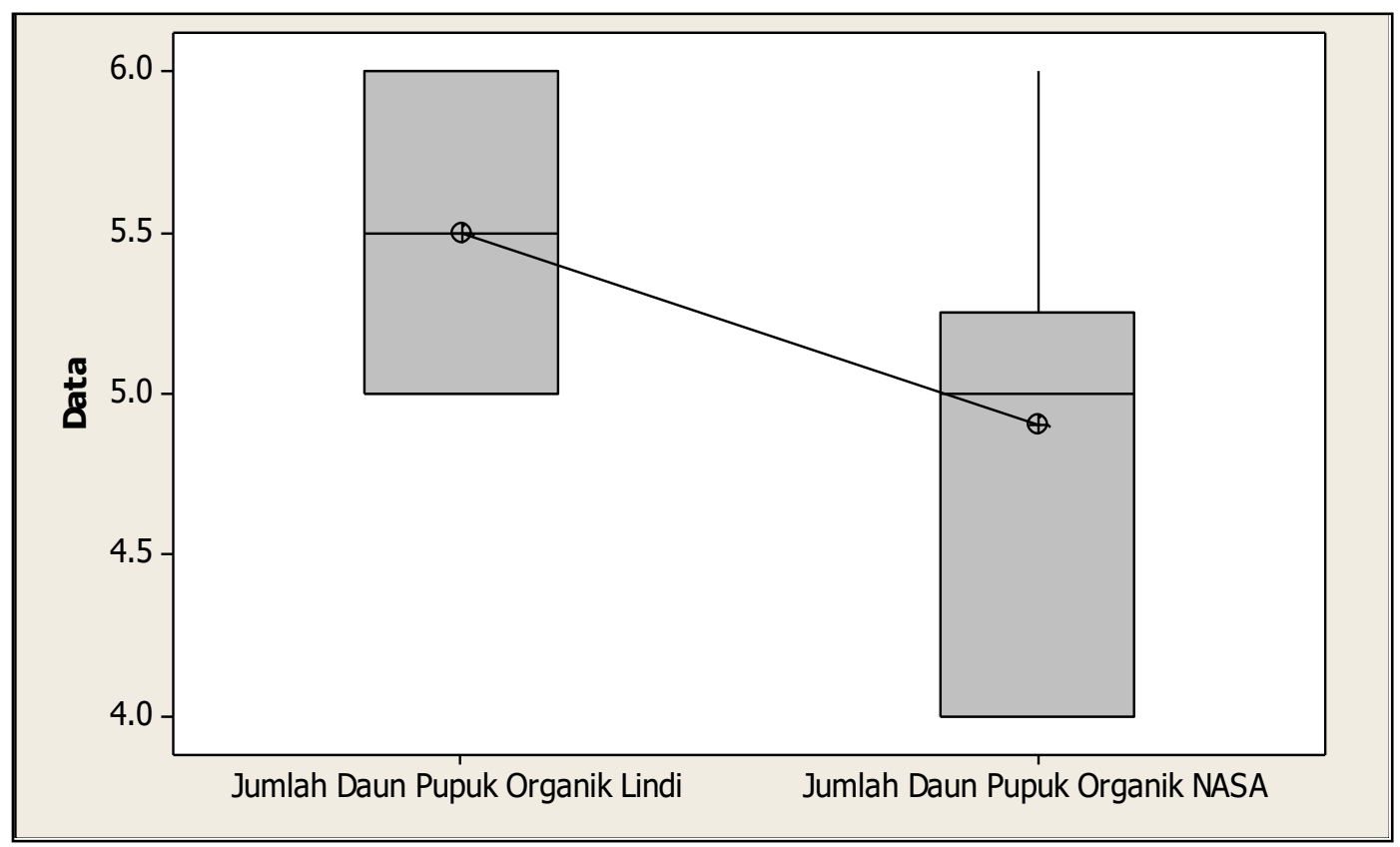

\section{Gambar 3. Grafik Boxplot yang Menggambarkan Nilai Tengah dan Nilai Sebaran Data Jumlah Daun Tanaman Seledri pada Pemberian Perlakuan Pupuk Organik Cair yang Berbeda}

Bertambahnya jumlah daun berakibat pada makin meningkatnya luas daun secara keseluruhan, hal ini berarti kemampuan tanaman untuk melakukan fotosintesis juga meningkat. Pertambahan jumlah daun juga berakibat pada pertambahan biomassa secara keseluruhan, terutama pada tanaman sayur seperti Seledri (Pracaya, 2009). Menurut Pranata (2004), unsur nitrogen merupakan unsur hara utama bagi pertumbuhan bagian-bagian vegetatif tanaman, seperti daun, batang, dan akar. Pada Tabel 1 dapat kita lihat bahwa kandungan Total $\mathrm{N}$ pada pupuk organik cair lindi cukup besar, yaitu $43.97 \mathrm{mg} / \mathrm{l}$. Dengan cepatnya pertambahan jumlah daun pada tanaman Seledri yang diberi perlakuan pupuk organik cair lindi di minggu pertama, maka hal tersebut mendorong pertumbuhan tanaman Seledri di minggu-minggu berikutnya, karena keberadaan daun tersebut juga meningkatkan proses fotosintesis.

Menurut Kurmarwiyah dan Erni (2011), fosfor dianggap penting dalam pembentukan energi sel (Adenosin Tri Phosphat/ATP). ATP terbentuk pertama kali pada proses fosforilisasi pada proses fotosintesis daun, dan kalium terlibat dalam proses reduksi $\mathrm{CO} 2$ dalam proses fotosintesis. Pada Tabel 1 dapat kita lihat bahwa kandungan $\mathrm{K}$ pada pupuk organik cair lindi tergolong besar, yaitu $454.09 \mathrm{mg} / \mathrm{l}$, hal inilah yang diprediksi membuat pupuk organik cair lindi memberikan efektivitas pertumbuhan yang baik terhadap tanaman Seledri.

\section{KESIMPULAN}

Dari hasil penelitian yang telah dilakukan, dapat diambil beberapa kesimpulan, yaitu:

1. Berdasarkan hasil analisis laboratorium, kandungan Total NPK pada pupuk organik cair berbahan dasar lindi dari TPA Telaga Punggur adalah $511.37 \mathrm{mg} / \mathrm{l}$.

2. Pemberian pupuk organik cair berbahan dasar lindi dari TPA Telaga Punggur berpengaruh signifikan dan erat terhadap pertumbuhan tanaman Seledri, dalam ini pertumbuhan tinggi tanaman dan pertambahan jumlah daun. 
3. Berdasarkan dosis yang diujicobakan, dosis pupuk organik cair lindi $14 \mathrm{ml} / \mathrm{L}$ memberikan hasil pertumbuhan terbaik. Walau demikian, dosis ini belum merupakan dosis optimal dan dapat dilakukan uji coba lebih lanjut dengan dosis yang lebih besar dari $14 \mathrm{ml} / \mathrm{L}$.

4. Apabila dilihat dari variabel pertumbuhan tinggi tanaman, secara statistik pupuk organik cair lindi dan pupuk organik cair NASA memberikan hasil pertumbuhan yang sama.

5. Apabila dari dari variabel pertambahan jumlah daun, secara statistik pupuk organik cair lindi memberikan hasil pertumbuhan yang lebih baik dibandingkan pupuk organik cair NASA.

\section{DAFTAR PUSTAKA}

Kusmarwiyah, R. dan Erni S. 2011. Pengaruh Media Tumbuh dan Pupuk Organik Cair terhadap Pertumbuhan dan Hasil Tanaman Seledri (Apium graveolens L.). Fakultas Pertanian - Universitas Mataram. Mataram.

Muhlisah, F. 1997. Pemanfaatan Tanaman Seledri untuk Obat dalam Buletin Minggu II Juni 1997. Yayasan Pers Indonesia. Jakarta.

Parnata, A.S. 2004. Pupuk Organik Cair: Aplikasi dan Manfaatnya. Agro Media Pustaka. Jakarta.

Pracaya. 2009. Bertanam Sayur Organik. Penebar Swaaya. Jakarta.

Puspita, L. 2007. Reduksi Senyawa Nitrogen, Fosfor, Konstituen Organik, dan TSS pada Air Lindi Limpasan dengan Rawa Buatan [Thesis]. Sekolah Pasca Sarjana - Institut Pertanian Bogor. Bogor.

Syahrudin. 2011. Respon Tanaman Seledri (Apium graveolens L.) terhadap Pemberian Beberapa Macam Pupuk Daun pada Tiga Jenis Tanah. Fakultas Pertanian Universitas Palangkaraya. Palangkaraya. 